\title{
Janet Frame: Foreword
}

Marta Dvorak

\section{(2) OpenEdition}

1 Journals

Electronic version

URL: https://journals.openedition.org/ces/7994

DOI: $10.4000 /$ ces.7994

ISSN: 2534-6695

\section{Publisher}

SEPC (Société d'études des pays du Commonwealth)

\section{Printed version}

Date of publication: 1 April 2011

Number of pages: 5

ISSN: 2270-0633

\section{Electronic reference}

Marta Dvorak, "Janet Frame: Foreword", Commonwealth Essays and Studies [Online], 33.2 | 2011, Online since 18 November 2021, connection on 06 January 2022. URL: http://journals.openedition.org/ces/ 7994 ; DOI: https://doi.org/10.4000/ces.7994

\section{(c) (1) (9)}

Commonwealth Essays and Studies is licensed under a Licence Creative Commons Attribution - Pas d'Utilisation Commerciale - Pas de Modification 4.0 International. 


\section{Foreword}

This issue of Commonwealth Essays and Studies is devoted to the extraordinary craft of Janet Frame, a recipient of the Commonwealth Writers' Prize whose spectacular life long overshadowed her art. The volume breaks ground by gathering reputed scholars from the Southern and Northern hemispheres who are acknowledged Frame specialists and/or who have published extensively on the genre of the short story to focus on Frame's iconoclastic short fiction, which to date has received considerably less attention than her novels.

The issue is the last one under my editorship (taken up in 2005 when former editor Jean-Pierre Durix retired). Throughout these six years the journal has garnered strong contributions and increased its international readership - available not only in the form of print copies (distributed by the Presses Sorbonne Nouvelle) but also on line (through the global aggregator ProQuest). I wish to thank the sterling group of contributors who have made this fine issue such an exciting event, and to thank Christine Lorre, who co-edited the issue with me, for her unflagging dedication, energy, and care. Thanks as well to Marie Ferré, the talented infographic artist who has vibrantly redesigned the journal's cover and graphics. I am grateful to the dedicated members of the Editorial Board and SEPC Executive Committee for their diligence and commitment, and I offer my warm thanks to the scholars in France and abroad who have involved themselves by serving on the Advisory Board with a combination of intellectual curiosity, openness, and high standards. Editing the journal has been a challenging but rewarding undertaking which has involved building networks of cooperation and fostering forms of collaboration which will ensure a smooth transition. The autumn issue 34.1 already in preparation, "Tectonic Plates: The Local and the Global," will prove to be an exciting one.

Marta DVORAK Editor-in-chief 